\title{
BLOOD DIGESTION \\ IN ORNITHODORUS MOUBATA MURRAY SENSU STRICTO WALTON FEMALES \\ (Ixodoidea : Argasidae)
}

\section{Modifications of midgut cells related to the digestive cycle and to the triggering action of mating}

\author{
O. GRANDJEAN*
}

SUMMARY. The cellular organisation of midgut cells (see Grandjean, in press) depends on the digestive cycle which follows a bloodmeal. The phases of this cycle are characterised in $O$. moubata, and various "cell-types" are described, correlated and discussed.

Mating triggers digestion : a) by an increased intracellular digestion (including the formation of heterophagolysosomes) during the rapid phase of digestion; b) by reactivating midgut cells in starving females, which then may perform vitellogenesis and lay few normal eggs.

La digestion du sang chez les femelles d'Ornithodorus moubata Murray sensu stricto Walton (Ixodoidea : Argasidae) :

II. Modifications des cellules du mésentéron, en relation avec le cycle digestif et l'action stimulante de copulations.

RÉSUMÉ. L'organisation cellulaire des cellules intestinales (voir Grandjean, sous presse) varie au cours du cycle digestif qui est déclenché par un repas sanguin. Les principales phases de ce cycle sont caractérisées chez $O$. moubata, et différents "types d'organisation " de cellules intestinales sont décrits, comparés et discutés.

La copulation active la digestion : a) chez les femelles nourries, elle intensifie la digestion intracellulaire, par une formation accrue d'hétérophagolysosomes; b) chez des femelles à jeun, elle réactive les cellules digestives et permet ainsi à la Tique de mobiliser ses réserves nutritives pour la vitellogenèse et la ponte de quelques œufs normalement constitués.

The present paper is a part of the PhD thesis presented at the University of Neuchatel, Switzerland, and has been partly supported by the SNSF grant 3.9160/72.

* Institut de Zoologie, Université de Neuchâtel, 2000 Neuchâtel 7, Suisse.

Accepté le 28 janvier 1983 . 


\section{1 - Introduction}

\subsection{Digestive cycle after ingestion of a bloodmeal}

The blood taken up by 0 . moubata is made available for the tick body mass and energy requirements by intracellular digestion (Grandjean, in press). This type of digestion is phylogenetically primitive, but well adapted to the ability of the ticks to survive over prolonged periods : the food reserves of the midgut lumen may be mobilised at a very low rate in a fasting tick. Due to the intracellular type of digestion, the midgut cells have to perform diversified functions which have to be coordinated between the single cells.

Sequential modifications of midgut cells are studied in relation with the digestive cycle. The latter is analysed mainly in mated females ; but virgin females were also considered in order to investigate the action of mating on digestion.

Midgut cells of males were also investigated to a lesser extent. No fundamental differences were found, as compared to those of females.

\subsection{Action of mating}

In adult females, energy and nutrient reserves provided by digestion of bloodmeals allow vitellogenesis and egglaying. Except in rare cases of parthenogenesis, mating is an absolute necessity for normal egglayings (Aeschlimann and Grandjean, 1973a).

Yet it is possible to induce vitellogenesis and egglaying in unfed females by delayed mating (without previous bloodmeal) or by injections of male gonad homogenates (Aeschlimann and Grandjean, 1973a; Germond and Aeschlimann, 1977; Ducommun, in prep.). The process of vitellogenesis following mating is dependent on an increased mobilisation of food reserves, which means an activation of digestive functions of the midgut epithelium. The triggering action on midgut cells may be demonstrated both for mating occuring at feeding time and for delayed mating in starving ticks.

\section{2 - Materials and Methods}

\subsection{Tick material}

O. moubata sensu stricto females, originally from Tanzania (Ulanga District) and bred according to Geigy and Herbig (1955), were fed on guinea-pigs, either in presence or in absence of males, and taken at various intervals after bloodmeal for gravimetric, histological or cytological investigations.

Other virgin females were fed and fasted during 110 days before males were added to half of them for delayed mating.

\subsection{Methods}

Histology $(H)$ : Tissue pieces fixed and embedded as for transmission electron microscopy were cut into sections of $1 \mu \mathrm{m}$ thickness and stained with toluidine blue ( $1 \%, 6$ parts + sodium carbonate $2,5 \%, 3$ parts + ethanol $70 \%, 1$ part.). 
Histochemistry $(H)$ : Pieces of midguts were fixed in either Carnoy's fluid, formaline or cold acetone before embedding into paraffine. Reactions such as PAS (including a diastase-fast control), pyronine-methyl green stain, cyanol (Fautrez and Lambert, in Gabe, 1968), benzidine (Pickworth, in Pearse, 1972) and Perl's blue (Burck, 1969) were performed. Attempts to stain for phosphatases or lipids did not succeed in a satisfactory manner.

Transmission Electron Microscopy (TEM) : See Grandjean (in press).

Scanning Electron Microscopy (SEM) : Midgut pieces were either fixed with formaline or ethanol $(70 \%)$ and dried in liquid nitrogen, or fixed as for Transmission Electron Microscopy and dried in air or liquid carbon dioxyde (Boyde and Wood, 1969). They were covered with a gold-carbon layer before observation with a Cambridge Mark II Stereoscan (Zurich : Cytological Laboratory of the Institute of General Botany, University of Zurich, Professor Hohl ; Basle : SEM-Laboratory, Institute of Geology and Paleontology, University of Basle, Dr. R. Guggenheim, fig. 26).

\section{3 - Modifications of Midgut Cells Related to Digestive Cycle}

\subsection{Definition of midgut cell "types" related to digestive cycle}

Histology $(\mathrm{H}$, including histochemistry) and ultrastructure (SEM = scanning electron microscopy, TEM = transmission electron microscopy) of cell types are described according to the digestive phases (fig. 1,23; table I ; see also Grandjean and Aeschlimann, 1973). After the unfed females (3.1.1, IV in fig. 1,23) have taken up blood, a "preparation phase" (3.1.2., I) is followed by a rapid phase of digestion (3.1.3., II and IIIa, up to IIIb and oviposition in mated females) which leads to the slow phase of digestion (3.1.6, IV) typical for fasting ticks.

\subsubsection{Unfed females}

$H$ : Cubical or columnar midgut cells contain few stained inclusions, except haematin granules and some rare lipid or glycogen inclusions ( fig. 1:IV).

SEM : The much infolded basal lamina is continuous with an organ investment layer, which covers also muscle, nerve and tracheolar cells (fig. 24). Seen from the interior of the midgut lumen, the apical surface of midgut cells is homogenously warty (fig. 25). Individual cells may not be distinguished.

TEM : "A-type" midgut cells : cubical (Grandjean and Aeschlimann, 1973 : fig. 4) or cylindrical midgut cells (fig. 2) contain numerous free ribosomes, some of which are associated with small vesicles (fig. $3: R$ ).

Inclusions or organites other than mitochondria and haematin granules are rare. The basal labyrinth is generally well developed.

\subsubsection{Gorged females}

$H$ : Cells of the midgut epithelium are submitted to an important stretching with feeding. Their inclusions are the same as in unfed ticks, at least immediately 


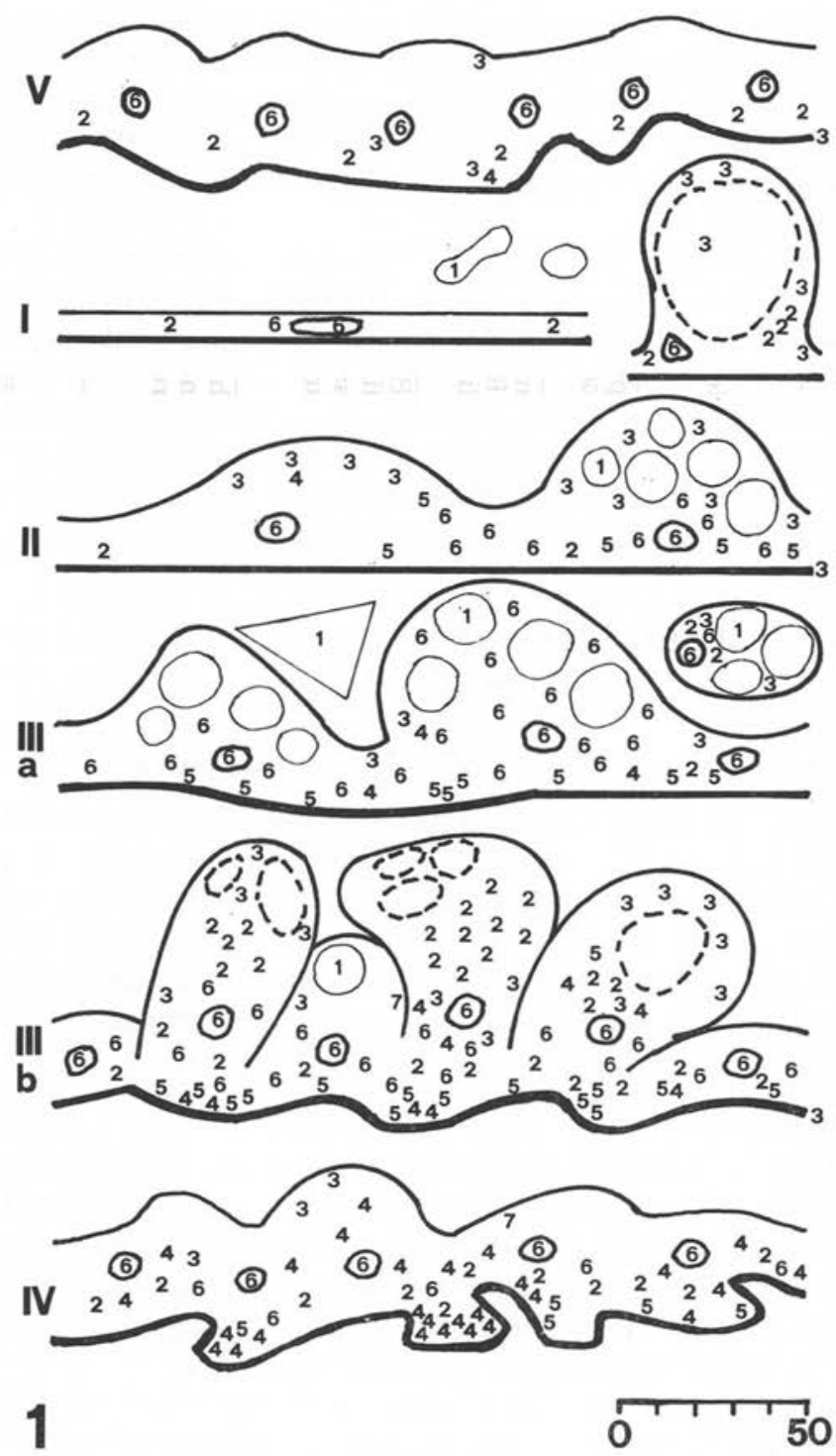

FIG. I. - Schematic drawing summarising histochemical results on the midgut cells of $O$. moubata. $\mathrm{I}=$ epithelium of newly gorged female, $\mathrm{II}=$ of female starting digestion, about 2 days after bloodmeal, III = of female, 6 (a) to $I_{5}$ (b) days after bloodmeal, IV $=$ of fasting female ; $\mathrm{I}=$ haemoglobin, green with Perl $+\mathrm{H}_{2} \mathrm{O}_{2}$, cyanol, 2 = haematin, blue with Perl $+\mathrm{H}_{2} \mathrm{O}_{2}$. $3=$ (muco)polysaccharides, diastasefast PAS positive, $4=$ glycogen, PAS positive, not resistant to diastase, $5=$ lipids, metachromatic toluidin blue or osmium tetroxyde, $6=$ ribonucleic acids (RNA), stained with pyronine, $7=$ free iron (Perl). 


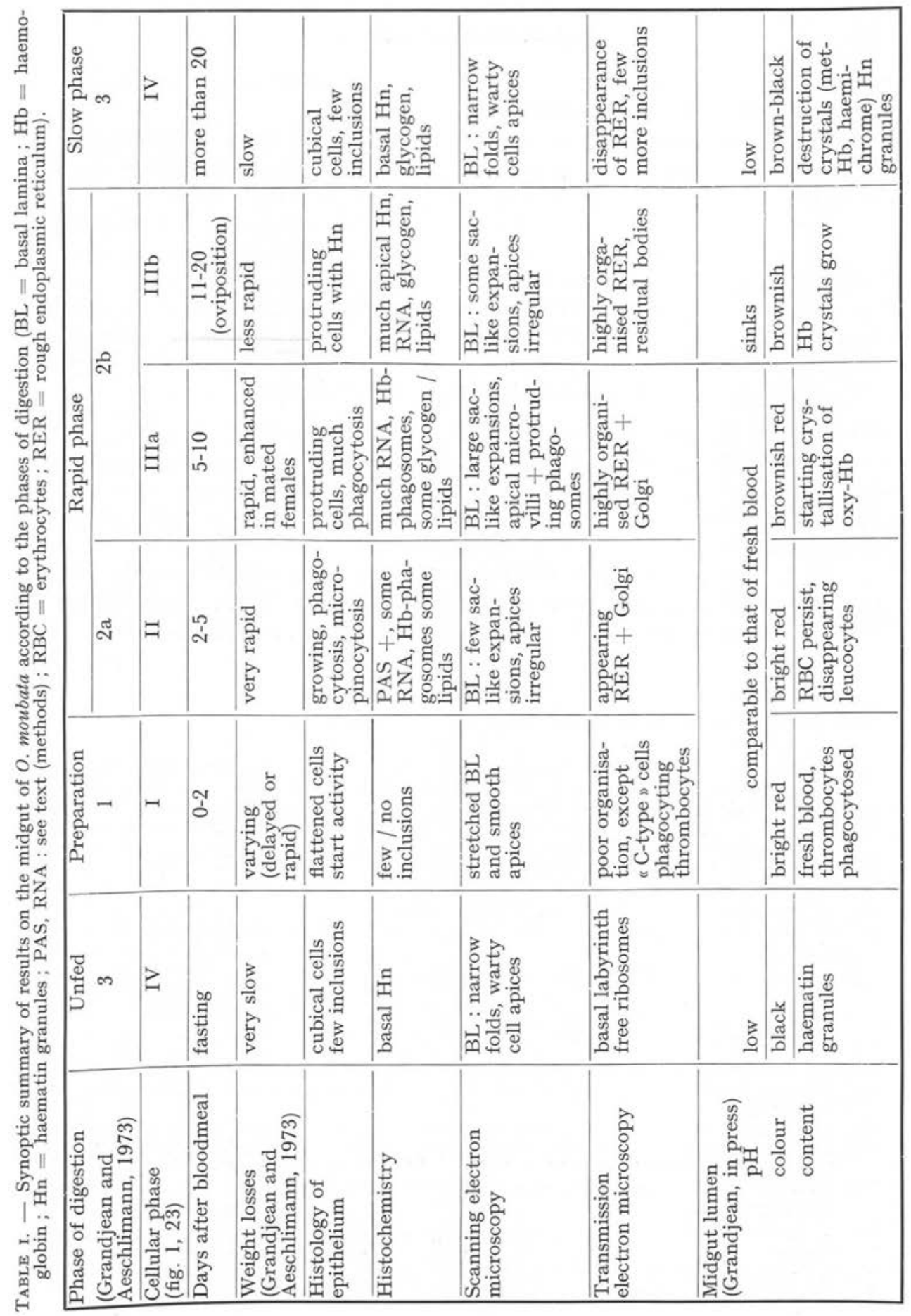


after feeding. Some protruding cells with a large vacuole reacted positively for (muco)polysaccharides (diastase-fast PAS-reaction; fig. $1: I$ ).

SEM : The important stretching action of blood entering the midgut during the bloodmeal is revealed as well on the external side of the midgut epithelium ( $f i g$. 26) as on the internal side ( fig. 27), if compared with unfed females ( $f i g .24,25$ ).

TEM : "B-type" : nuclei are stretched within the strongly flattened midgut cells (fig. 4) and the few organites or inclusions, such as mitochondria or haematin granules, are squeezed between the basal lamina and the apical cell membrane.

"C-type" : protruding cells with huge vacuoles and a thin peripheral cytoplasm layer (gv and pc in fig. 3, and Grandjean, in press : fig. 16) are either teared off or remain attached with the entry of fresh blood. In both cases they are able to perform early phagocytic activity in absorbing mainly thrombocytes.

\subsubsection{Start of digestion (from the second day after bloodmeal).}

$H$ : The growing cells start reacting positively for RNA and often for (muco)polysaccharides. Glycogen and lipids may be found. Slightly protruding cells contain vacuoles with haemoglobin : pseudopodia-like expansions of the cell allow phagocytosis of erythrocytes.

TEM : "D-type" : midgut cells which start absorbing material from the midgut lumen by micropinocytosis have a well developed basal labyrinth. Their elongated RER saccules are found mainly along the lateral part and the basal invagination of

General key to abbreviations (excepting fig. 1 and 23).

$\mathrm{a}=$ special cell membrane-associated, paired RER saccules (See Grandjean, in press), $\mathrm{e}=$ erythrocyte, $\mathrm{gl}=$ glycogen, $\mathrm{gv}=$ great clear vacuole, $\mathrm{h}=$ haematin granule, ic $=$ intercellular space, $\mathrm{m}=$ mitochondria, $\mathrm{mp}=$ micropinocytotic vesicles, $\mathrm{mt}=$ microtubules, $\mathrm{mv}=$ microvilli, $\mathrm{n}=$ nucleus, $\mathrm{nl}=$ nucleolus, $\mathrm{pc}=$ peripheral cytoplasm layer, $\mathrm{r}=$ ribosomes, $\mathrm{rb}=$ residual body, $\mathrm{za}=$ zonula adhearens.

$\mathrm{BL}=$ basal lamina, $\mathrm{G}=$ dictyosome (Golgi system),

$\mathrm{L}=$ midgut lumen, $\mathrm{Li}==$ lipids, $\mathrm{M}=$ muscle cell,

$\mathrm{P}=$ phagosome, $\mathrm{R}=$ rough endoplasmic reticulum,

$\mathrm{SL}=$ secondary lysosomes, $\mathrm{T}=$ tracheole, $\mathrm{W}=$ Wolbachia $s p$. (rickettsia like microorganism).

For each figure, the scale is expressed in micrometers $(\mu \mathrm{m})$.

Fig. 2. - Apical part of cylindrical midgut cells of an unfed female, with a cell undergoing lysis $\left(^{*}\right)$.

Fig. 3. - Detail of the apical part of midgut cells of unfed female, one cell possessing a large clear vacuole (gv).

Fig. 4. - Flattened, distended cell of a gorged female, immediately after completion of feeding, with a monocyte in the midgut lumen (arrow = "organ investment layer" surrounding midgut muscle and tracheal cells).

Fig. 5. - Flattened midgut cell, starting uptake of material from lumen, I day after bloodmeal (arrow as in fig. 4).

Fig. 6. - Detail of cell as in fig. s $\left(^{*}=\right.$ lacunar extracellular space ; note appearance of long RER saccules, $\mathrm{R})$.

Fig. 7. - Growing and developing cubical midgut cell, 2 days after bloodmeal, with developing dictyosomes and stacks of RER, and with reserve inclusions. 

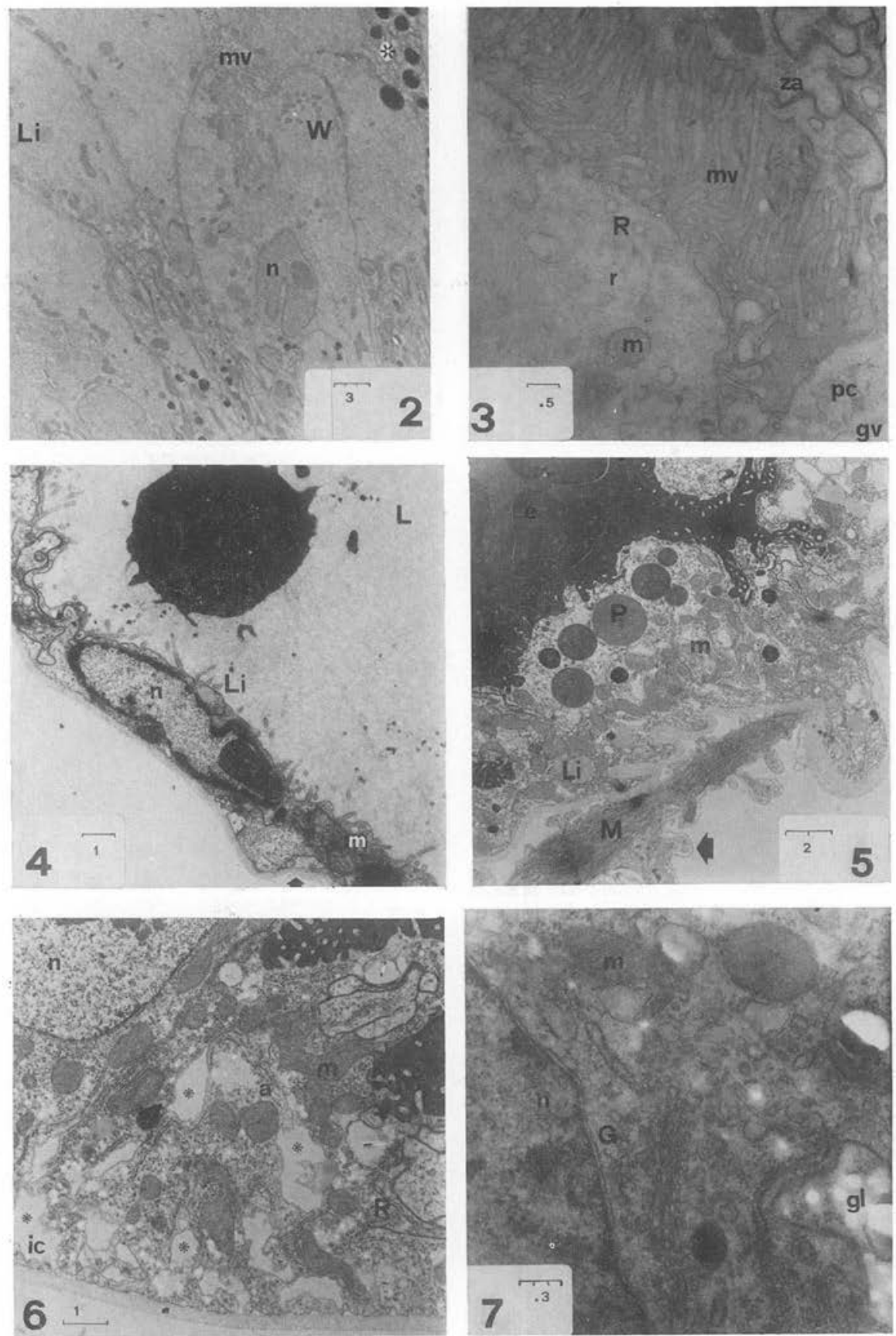

FIG. 2-7. 

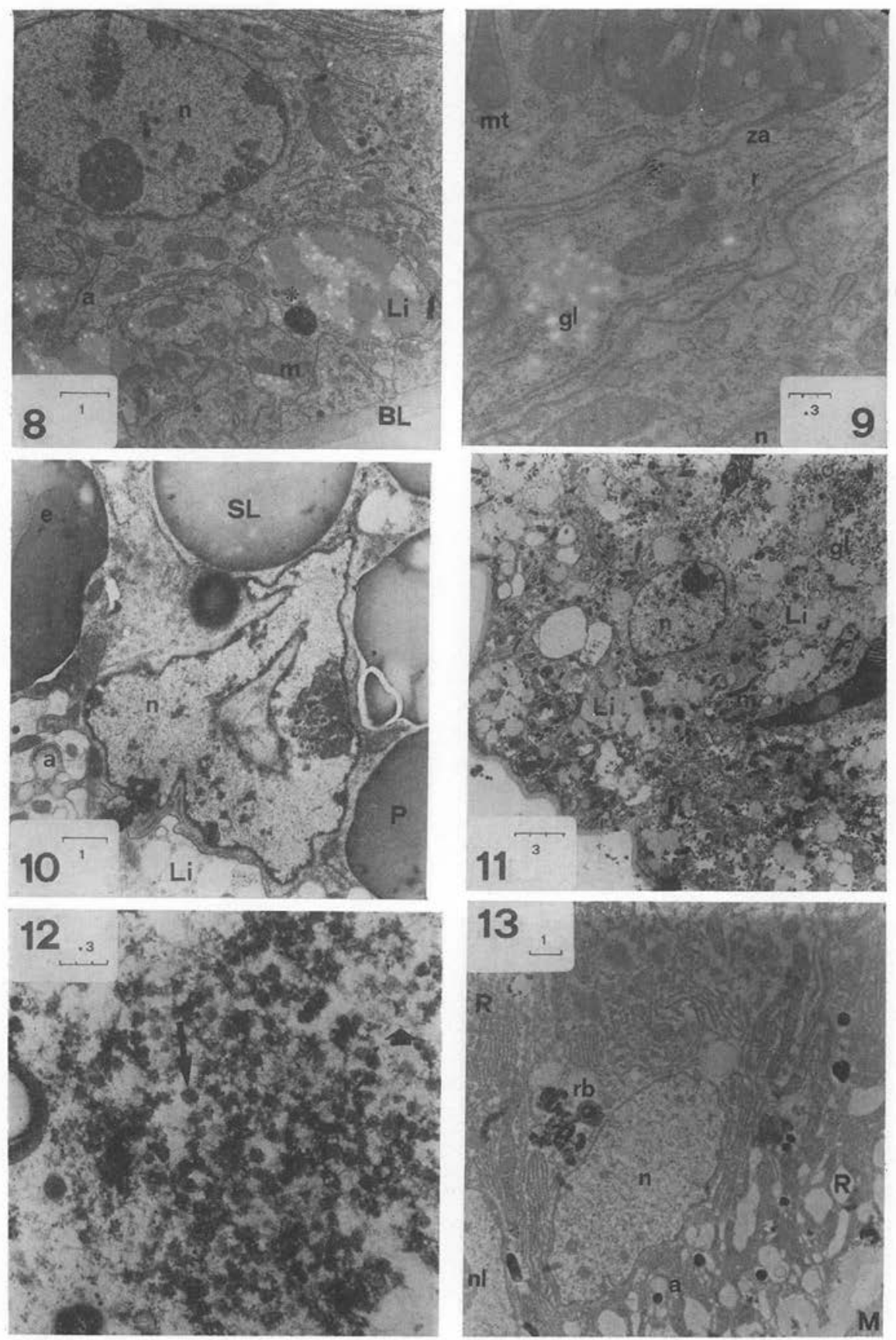

FIG. 8-I3. 
the cell membrane (fig. 6). These cells contain some lipid inclusions in their basal part (fig. $5: \mathrm{Li}$ ).

"E-type" : growing midgut cells change from a flat to a cubical shape and undergo important differenciation with the appearance and the organisation of rough endoplasmic reticulum (RER) and of dictyosomes ( fig. 7). Lipid and glycogen reserves may be found in these cells.

"F-type" : protruding cells which absorb erythrocytes by phagocytosis ( fig. 14) have a very similar cellular organisation as compared with cubical cells ("E-type").

"G-type" : some large protruding cells digest intracellularly phagocytosed thrombocytes (fig. 23: G).

3.1.4. Full digestive activity (about 5 to 8 days after bloodmeal) $H$ : The numerous protruding cells contain haemoglobin in their vacuoles. Their cytoplasm is scattered with RNA material ; lipid inclusions and some glycogen may be found in the basal part of the cells.

SEM : Externally (fig. 28) the fully active midgut epithelium forms sac-like expansions between the muscle cords allow an ampliation of the epithelial basement surface. Individual protruding cells loaded with food material may be recognised if seen from inside the midgut lumen ; they are covered by a coat of well distinguishable microvilli ( fig. 29).

TEM : "H-type" : These cubical cells show a very high level of cellular organisation. RER saccules are often arranged in stacks (fig. 15:R) and dictyosomes are well differenciated (Grandjean, in press : fig. 18). Lipid (fig. 8) and glycogen (fig.9) inclusions are present and micropinocytotic processes still may be observed (Grandjean and Aeschlimann, 1973 : fig. $6 a$ ).

"I-type" : protruding cells, loaded with food material from the lumen (mainly phagocytosed erythrocytes) do not greatly differ in their organisation from the cubical cells ("H-type", fig. 15). Basal lipid inclusions are often found (fig. 10). Ultrastructural changes occuring within food vacuoles (phagosomes, phagolysosomes) have been described (Grandjean, in press).

"J or K-type" : few cubical or cylindrical cells contain food inclusions, numerous residual bodies ( fig. 13:rb) and a poorly developed, rather vesicular RER.

"L-type" : several cells were nearly filled with lipid or glycogen inclusions (fig. 11, 12).

Fig. 8. - Cubical midgut cells, 5 days after bloodmeal, showing well differenciated cell structures ${ }^{*}=$ smooth vesicle with a haematin granule being formed).

Fig. 9. - Apical detail of a midgut cell, 5 days after bloodmeal.

Fig. 10. - Detail of central part of protruding cell loaded with phagosomes (P) and early secondary lysosomes (SL), 6 days after bloodmeal (see also fig. 1 s).

Fig. II. - Protruding midgut filled with reserve inclusions (glycogen and lipids), 8 days after bloodmeal.

Fig. I2. - Detail of fig. II with alpha (thin arrow) and beta (small thick arrow) glycogen granules.

Fig. 13. - Basal part of midgut cell as drawn in fig. 16, with very much developed RER. 

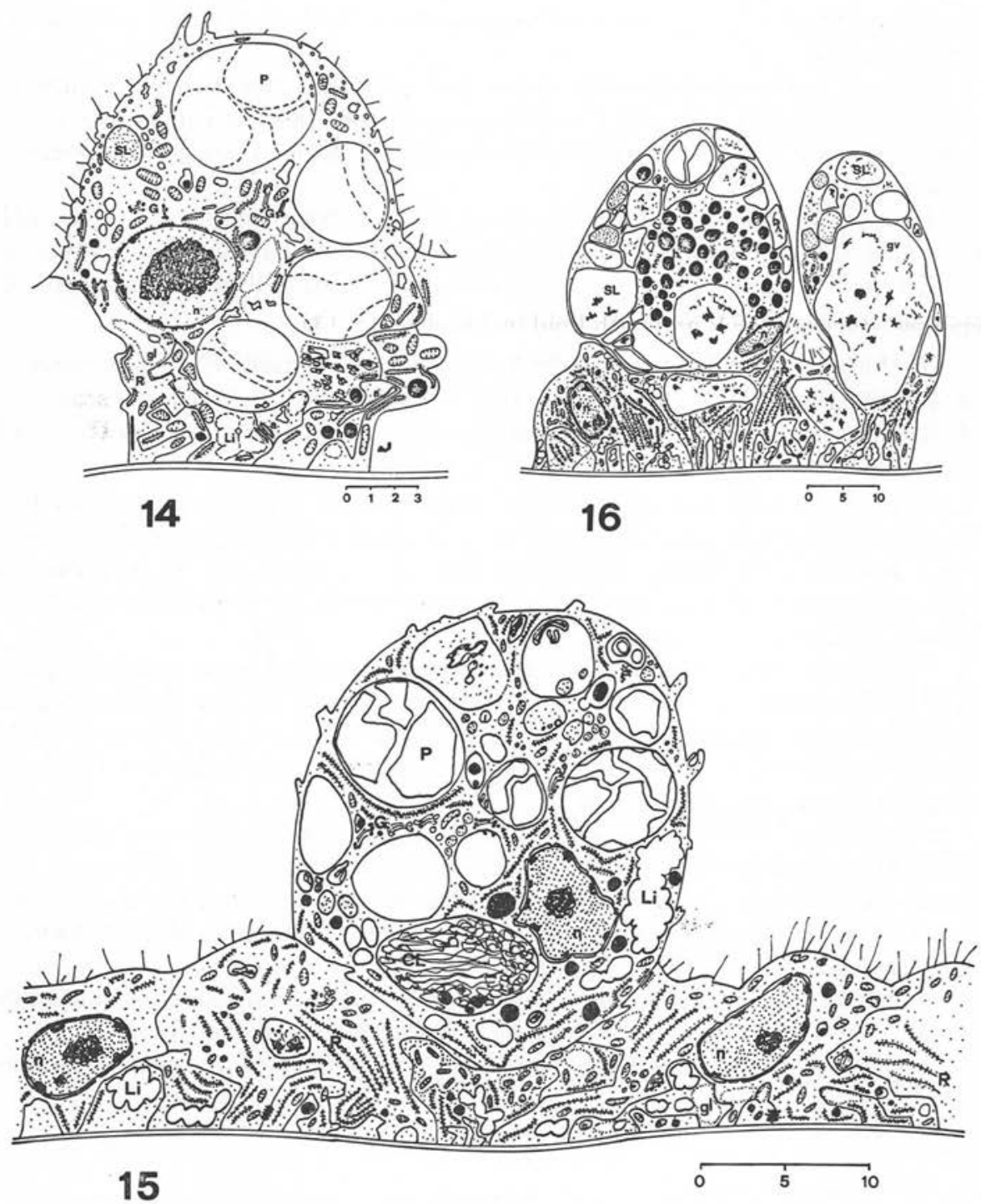

FIG. I4-I6.

Fig. 14. - Schematic drawing of slightly protruding midgut cell filled with phagosomes (phagocytosed erythrocytes), 2 days after bloodmeal.

Fig. 15. - Schematic drawing of several cubical and one protruding midgut cells, the latter being filled with digestive vacuoles (secondary) lysosomes), 5 days after bloodmeal.

Fig. I6. - Schematic drawing of protruding midgut cells having completed digestion, 17 days after bloodmeal, with late secondary lysosomes (clear vacuoles with some granulations, see Grandjean, 1982) and accumulation of haematin granules. 
3.1.5. Advanced stages of rapid phase of digestion (about 15 to 20 days after bloodmeal).

$H$ : Numerous protruding cells are filled with haematin granules in their central part. Clear apical vacuoles, (muco)polysaccharides are present there. Lipid and glycogen reserves are mainly bound to the basal parts of the cells which contain also RNA material. Some free iron could be detected (fig. 1), but this seems to be an exception, as iron normally remains bound in the haematin.

TEM : "M-type" : in the large protruding cells, the centrally accumulated haematin granules ( $f i g .16$ ) are surrounded by numerous vacuoles (late secondary lysosomes, Grandjean, in press ; fig. 23). The basal part of these cells is filled with highly organised stacks of RER and with lipid inclusions ( fig. 13).

"N-type" : cubical cells of this stage contain a well developed RER and important lipid and glycogen reserves.

3.1.6. Slow phase of digestion (fasting females, more than 20 days after bloodmeal, after oviposition).

$H$ : The mainly cubical midgut cells contain haematin granules, some lipid and more numerous glycogen inclusions. RNA material has almost disappeared.

$S E M$ : External and internal surfaces of the midgut epithelium may hardly be distinguished from those of unfed females ( fig. 24, 25).

TEM : "O-type" : cell organites and inclusions at this phase may be compared to those of unfed females. RER is no longer arranged in stacks, but rather composed of few vesicular elements ( $f$ g. 17). Lipids and glycogen are stored. Several protruding cells contain huge vacuoles ( fig. 17: gv; fig. 23: "Oc-type”).

\subsection{Postulated relationships between cell "types"}

\subsubsection{Cell transformations due to feeding activity of the tick.}

The arrival of fresh blood is responsable for a dramatical mechanical stretching of the midgut epithelium and the tearing off of numerous midgut cells, which will be lysed in the lumen. It also triggers phagocytic activity in some midgut cells which attack mainly thrombocytes (fig. 23 : "C-type" cells which are present also in the epithelium of unfed or starving ticks as the "Ac-type").

\subsubsection{Growth and activation of cells after the bloodmeal.}

A deep cellular reorganisation of the stretched migdut cells is triggered by the arrival of blood. Differenciation includes the growth of the cell and leads to a well developed and functional system of organites, such as RER and Golgi apparatus, which will allow intracellular digestion of blood within a lysosomial system. The cellular reorganisation appears to be synchronous in most of the midgut cells and lasts for 1 or days, which correspond to the "preparation phase" before start of rapid digestion.

3.2.3. Fate of protruding cells loaded with food vacuoles (phagosomes and secondary lysosomes).

Midgut cells start protruding into the lumen by taking up food material ( $f i g .23$ : 

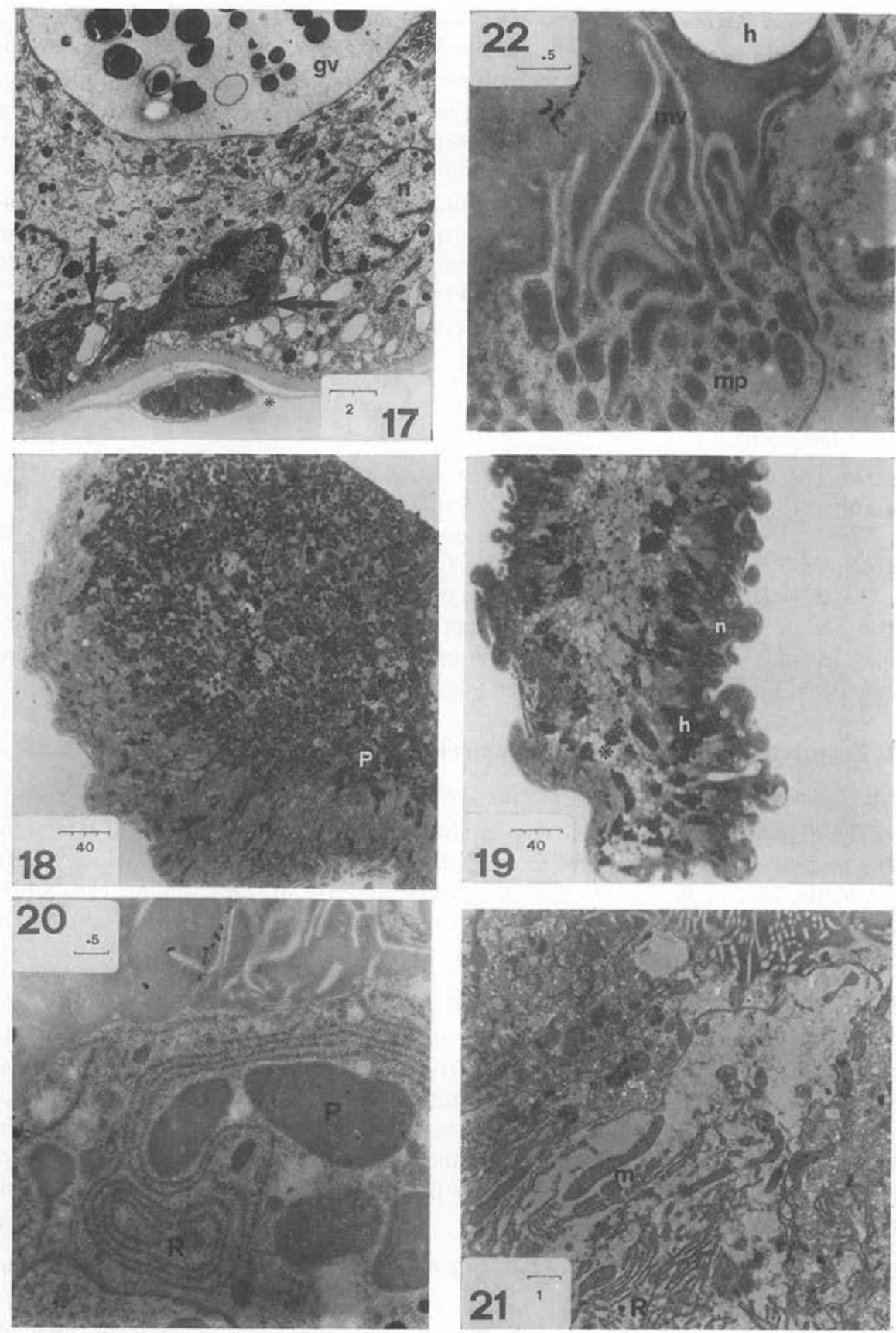

FIG. 17-22. 


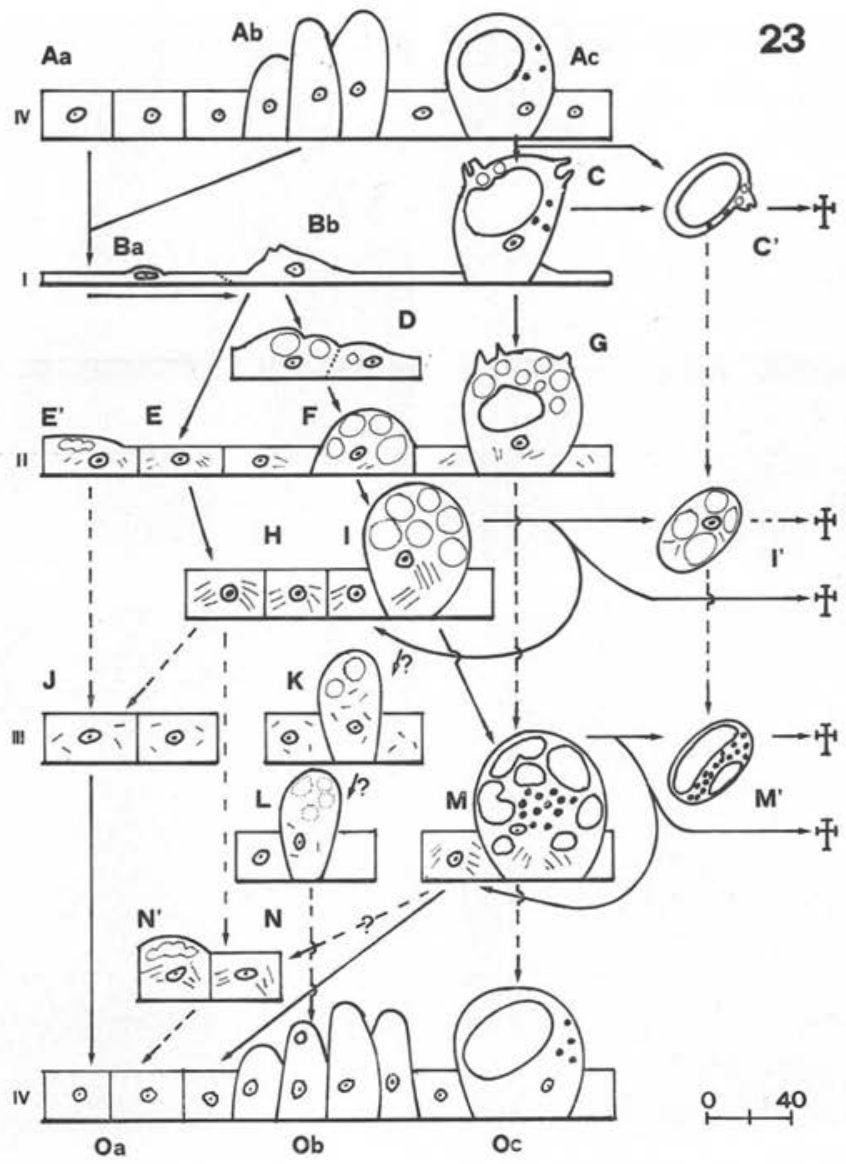

FIG. 23. - Schematic drawing summarising the cell types described and showing their postulated inter-relationships (A to O, see text, 3.I ; I to IV, as in fig. $I$ and in Grandjean \& Aeschlimann, 1973).

Fig. I7. - Cubical midgut cells, 26 days after bloodmeal, with one cell apically filled with a huge vacuole (gv) containing haematin granules and two cells with a gross granular content (arrows) ${ }^{*}=$ organ investment layer.

Fig. I8. - Midgut histology of virgin females, I7 days after bloodmeal, with protruding cells filled with undigested haemoglobin vacuoles $(\mathrm{P})$.

Fig. I9. - Midgut histology of mated female, I 7 days after bloodmeal, with numerous cells filled with haematin granules (h) and clear vacuoles $(*)$.

Fig. 20. - TEM : apical part of midgut cell of virgin female, I 7 days after bloodmeal (note "whorl"' like arrangement of RER).

Fig. 21. - TEM : apical part of midgut cell of mated female, 17 days after bloodmeal.

Fig. 22. - TEM : apical detail of cell like fig. 20 (virgin female). 

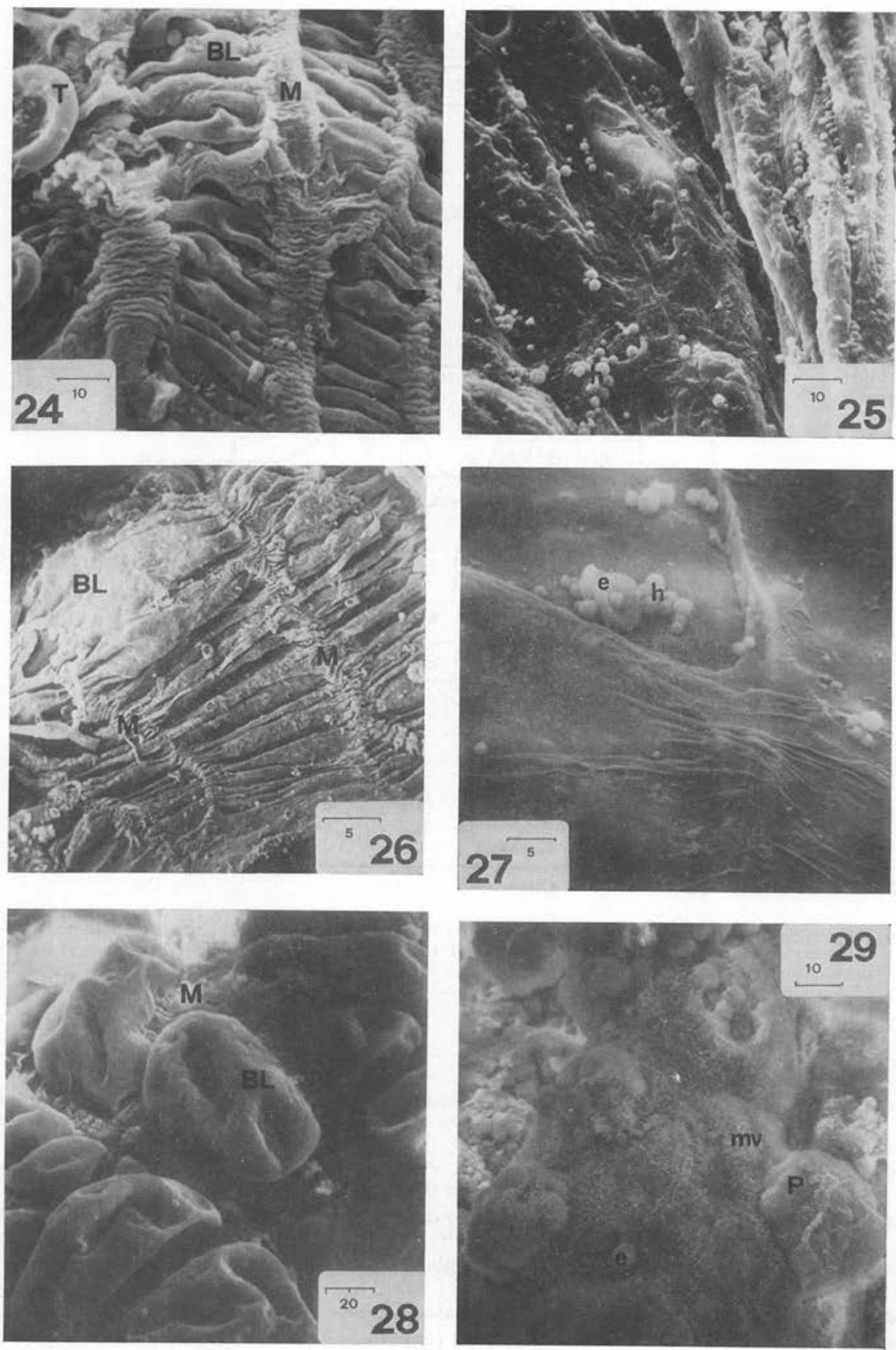

FIG. 24-29. 
"D or F-type") up to important quantities (see "I-type”). With progress of intracellular digestion, clear vacuoles are formed (see "M-type") which may fuse together. Thus certain cells ("Oc-type”) may contain huge vacuoles for very long periods ("Ac-type").

Some cells may be observed to disrupt after completion of digestion. Others detach from their bases, either with or without nucleus, and float within the lumen before lysis. Cubical cells in fasting ticks might originate from protruding cells having completed digestion and lost their apical parts ( fig. 23).

\subsubsection{Synthetic activities of the midgut cells}

Early differenciation of midgut cells is linked to the needs for synthesis of digestive enzymes (proteases ; Akov et al., 1976, see also Grandjean, in press). Midgut cells having completed digestion ( fig. 23: "M and N-type") still possess a highly organised RER, which suggests that proteins might be synthetised from material mobilised by digestion. As such cells are numerous during the preoviposition period of females, there is much evidence for them to play an important role for the synthesis of vitellogenins, as postulated earlier (Diehl, 1970). Cells of the fat body probably also are involved (Obenchain, personal communication). The mechanisms of exocytosis and release of vitellogenins from the midgut cells into the lumen still remain unknown; special basal cell membrane-associated RER saccules (Grandjean, in press) could possibly be involved.

\subsubsection{Cubical cells and cell renewal}

During all digestive phases, some cells do not participate in the actual digestion of blood. They are generally cubical, may be highly organised and start to take up food and digest it at once. Cubical cells also result from mitotic divisions, even if the latter are hardly ever observed (Grandjean and Aeschlimann, 1973). Small cells with gross granular elements ( $f i g .17:$ arrows) are like the replacement cells in Aedes aegypti midguts (Hecker et al., 1971a,b).

\subsubsection{Other cell types}

The other cell types described ( fig. 23 : “J, K, L-type”) were not often encountered and apparently do play a less important role in digestion.

Fig. 24. - SEM : external face of midgut epithelium of unfed female, showing folded basal lamina (BL) which is continuous (arrows, as in fig. 4) with organ investment layer covering muscle (M) and tracheolar (T) cells (acceleration : $18 \mathrm{kV}$ ).

Fig. 25. - SEM : internal face of midgut epithelium of unfed female, showing homogenous warty appearance of the surface of cell apices $(\mathrm{h}=$ haematin granules; acceleration $\mathrm{I} 8 \mathrm{kV})$.

Fig. 26. - SEM : external face of midgut epithelium of freshly gorged female with stretched basal lamina (compare distance between muscle cords, M, with fig. 24; acceleration Io kV).

Fig. 27. - SEM : internal face of stretched midgut epithelium as in fig. 26, the surface of cell apices being smooth and poorly differentiated ( $\mathrm{e}=$ erythrocyte ; acceleration : $20 \mathrm{kV})$.

Fig. 28. - SEM : external face of midgut epithelium of female, in the phase of rapid digestion (5 days after bloodmeal), showing sac-like expansions of basal lamina between muscular strings (acceleration : $20 \mathrm{kV}$ ).

Fig. 29. - SEM : internal face of midgut epithelium as in fig. 28 , showing apices of protruding cells loaded with phagolysosomes $(\mathrm{P})$ and covered with microvilli ( $\mathrm{mv}$; $\mathrm{e}=$ erythrocyte : spherical, not yet lysed; acceleration : $20 \mathrm{kV}$ ). 


\subsection{Homogeneity of digestive activity in the various midgut diverticula}

In cell counts, the percentage of midgut cells which contained haemoglobin vacuoles was chosen as being representative of the cell population actually involved in processes of intracellular digestion (table II). Shortly after bloodmeal, midgut cells absorbing haemoglobin are more numerous in the anterior and medial diverticula than in the other parts of the midgut. These diverticula have been found, mainly in their distal parts, to become less stretched with arrival of fresh blood than e.g. the central part of the midgut.

After some 5 to 8 days, all the parts of the midgut appear to be equally involved in absorptive and digestive activities, as the half to three quarters of the cells contain haemoglobin. About 2 weeks after bloodmeal, the number of cells with digestive activity diminishes more rapidly in the anterior and medial diverticula than in the central and posterior parts of the midgut. In fasting ticks or unfed females, few midgut cells are responsable for slow digestion ; they are more numerous in the central and posterior parts of the midgut which might therefore be considered to perform mainly storage functions.

TABLE II. - Percentage of midgut cells containing haemoglobin inclusions, according to their localisation in the midgut and at various intervals after bloodmeal

\begin{tabular}{ccrrrr}
\hline $\begin{array}{c}\text { Days after } \\
\text { bloodmeal }\end{array}$ & $\begin{array}{c}\text { Number of cells } \\
\text { counted }\end{array}$ & $\begin{array}{c}\mathrm{a}, 1 \\
(\%)\end{array}$ & $\begin{array}{c}\mathrm{p}, \mathrm{c} \\
(\%)\end{array}$ & $\begin{array}{c}\text { total } \\
(\%)\end{array}$ & $\begin{array}{c}\mathrm{a}, 1 \\
\mathrm{p}, \mathrm{c}\end{array}$ ratio* \\
\hline fasting & 357 & 1,6 & 5,6 & 4,2 & 0,28 \\
0 & 384 & 26,5 & 11,6 & 16,6 & 2,28 \\
1 & 322 & 25,7 & 26,1 & 31,7 & 0,99 \\
2 & 283 & 67,9 & 44,0 & 50,0 & 1,54 \\
5 & 370 & 66,3 & 49,1 & 58,6 & 1,35 \\
$6-7$ & 148 & 49,0 & 52,0 & 53,4 & 0,94 \\
8 & 290 & 74,8 & 72,4 & 71,8 & 1,03 \\
12 & 111 & 30,0 & 34,0 & 32,4 & 0,88 \\
$15-18$ & 109 & 7,0 & 14,0 & 11,9 & 0,50 \\
$(\mathrm{~m})$ & 111 & 45,7 & 66,7 & 51,3 & 0,68 \\
$(\mathrm{v})$ & 373 & 6,7 & 8,6 & 7,8 & 0,78 \\
$20-22$ & 117 & 5,0 & 5,9 & 6,0 & 0,85 \\
$30-35$ & & & & & \\
\hline
\end{tabular}

( $\mathrm{a}=$ anterior, $1=$ lateral, $\mathrm{p}=$ posterior diverticula, $\mathrm{c}=$ central part of midgut, $\mathrm{m}=$ mated, $\mathrm{v}=$ virgin females).

* Ratio 1 means that digestive activity is homogenously present in all parts of the midgut,

ratio $>1$ indicates predominance of digestive activity in the anterior and lateral diverticula,

ratio $<1$ indicates predominance of digestive activity in the central part and the posterior diverticula of the midgut. 


\subsection{Discussion}

\subsubsection{Phases of the digestive cycle}

A distinction between a rapid and a slow phase of digestion has been established for argasids, according to the protein content of the midgut (Akov et al., 1976) and to general metabolic activity of the tick (Hajjar, 1971). It corresponds to definitions of digestive phases by Balashov (1961, from state of midgut content) and Tatchell (1964, from haemoglobin concentration of midgut content). According to our findings for O. moubata (Grandjean and Aeschlimann, 1973, Grandjean, in press and present paper ; resumed in table $I$ ), a short period of preparation, immediately after bloodmeal, is followed by a rapid and a slow phase of digestion. Midgut cytology and biochemistry, as well as weight losses of the tick are related to the digestive phases.

\subsubsection{Cell-"types" in the midgut epithelium of ticks}

\section{a) Comparison with other argasids}

The several "types" of midgut cells of $O$. moubata may be explained by following the fate of one single, changing cell ( fig. 23 ; e.g. stretched - growing - dividing - absorbing - digesting - lysis or persisting cell with a large vacuole - phygocytic activity after bloodmeal - digestion of thrombocytes - lysis). In this we would agree with Tatchell (1964: Argas persicus) or Guirgis (1971: A. arboreus), who assert that the cells may have various functions, rather than with Balashov (1972) who describes three distinct types of cells (reserve, digesting and secreting cells). The interpretation of cubical cells as remnants of partly detached protruding cells has been supported by autoradiographic evidence (Khalil, $1971:$ A. arboreus).

The activity of early phagocytosis by "C-type" cells is not identical with that of cells digesting haemoglobin after differenciation and has not yet been reported so far. These cells could possibly be interpreted as identical to the secreting cells found shortly after bloodmeal by Balashov (1972).

\section{b) Comparison with ixodids}

During the slow feeding phase of $H$. asiaticum nymphs, Balashov and Raikhel (1976) have found secreting cells with cytological features different to any of the midgut cell "types" in O. moubata. They describe other cells which perform phagocytosis and pinocytosis, mainly in the central parts of the midgut. Such cells could be compared to "C or G-type" of early phagocyting cells in O. moubata. Few midgut cells filled with haemoglobin vacuoles (comparable to "I-type") were found by the same authors.

Cubical cells with developing RER, dictyosomes and appearing lipid inclusions in the midgut of $D$. andersoni females (Belozerov and Timopheev, 1971: during slow phase of preliminary feeding) could be compared to the "E-type" found in O. moubata during the preliminary preparing phase of digestion after bloodmeal.

Large cells with numerous haemoglobin vacuoles increase in number during the rapid phase of feeding and final engorgement of ixodids (Belozerov and Timopheev, 
1971 : Balashov and Raikhel, 1976). After ixodids have dropped off their host, their midgut cells must undergo a second differenciation before rapid digestion may be fully accomplished.

Histological modifications of midgut cells are well synchronised in ixodids (Balashov, 1972), whereas in argasids, they are less strictly dependent on the digestive cycle. This is coherent with the "all-or-none" sequence of biological events (such as vitellogenesis, egg-laying and death) observed to a larger extent in ixodids than in argasids (Aeschlimann and Grandjean, 1973a).

\subsubsection{Homogeneity of midgut diverticula}

Our results differ from those of Guirgis (1971) or Balashov (1972) in showing that posterior diverticula are able to perform important digestive functions and not only to serve as a storage organ. We agree with the conclusions of Khalil (1971), that the rapid phase of digestion involves rather anterior, and the slow phase rather posterior midgut cells. Yet midgut cells of posterior diverticula are also active in the rapid phase of digestion in O. moubata.

\section{4 - Triggering Action of Mating}

\subsection{Effects of mating approximately synchronous with bloodmeal}

\section{a) Effects on mutrition}

Nutrition is completely independent on mating, as well for the amount of blood taken in as for duration of bloodmeal (table III, see also Aeschlimann and Grandjean, 1973a).

TABLE III. - Nutritional parameters in mated and unmated O. moubata females.

\begin{tabular}{lcc}
\hline & $\begin{array}{c}\text { mated females } \\
(\mathrm{n}=14)\end{array}$ & $\begin{array}{c}\text { unmated females } \\
(\mathrm{n}=14)\end{array}$ \\
\cline { 2 - 3 } & $424 \pm 68$ & $420 \pm 59$ \\
$\frac{\text { fed weight }}{\text { unfed weight }}(\%)$ & $47 \pm 17$ & $42 \pm 20$ \\
$\begin{array}{l}\text { duration of bloodmeal } \\
\text { (minutes) }\end{array}$ & $42 \pm 17$ \\
\hline
\end{tabular}

b) Effects on digestion: gravimetric analysis

Virgin females loose their weight less rapidly than mated ones (Grandjean and Aeschlimann, 1973). The difference arises at the time of vitellogenetic activity of the mated tick (table IVa: about 10 days). 
TABLE IV. - Weight losses of female ticks following mating, compared to unmated controls, both :

\begin{tabular}{|c|c|c|c|c|c|}
\hline \multirow[b]{2}{*}{$\begin{array}{l}\text { Days after } \\
\text { mating }\end{array}$} & \multicolumn{3}{|c|}{$\begin{array}{l}\text { a) mating synchronous } \\
\text { with bloodmeal }\end{array}$} & \multicolumn{2}{|c|}{ b) delayed mating } \\
\hline & mated $(\mathrm{n}=14)$ & $\begin{array}{l}\text { unmated } \\
(\mathrm{n}=14)\end{array}$ & t-test & $\begin{array}{c}\text { mated } \\
(\mathrm{n}=10)\end{array}$ & $\begin{array}{l}\text { unmated } \\
(\mathrm{n}=6)\end{array}$ \\
\hline 0 & 100,0 & 100,0 & - & 100,0 & 100,0 \\
\hline 4 & & & & 98,1 & 98,5 \\
\hline 5 & $88,8 \pm 2,2$ & $89,0 \pm 3,4$ & 一 & & \\
\hline 7 & $86,5 \pm 1,5$ & $87,3 \pm 3,6$ & - & 95,5 & 96,6 \\
\hline 8 & $85,0 \pm 1,9$ & $86,8 \pm 3,8$ & $(-)$ & & \\
\hline 10 & $82,6 \pm 1,6$ & $85,0 \pm 4,5$ & + & 93,7 & 95,0 \\
\hline $\begin{array}{l}14 \\
15\end{array}$ & $797+17$ & & & $91,1^{*}$ & $93,0 *$ \\
\hline $\begin{array}{l}15 \\
18\end{array}$ & $\begin{array}{l}79,7 \pm 1,1 \\
79,0 \pm 1,9\end{array}$ & $\begin{array}{l}82,4 \pm 4,5 \\
81,6 \pm 4,8\end{array}$ & $\begin{array}{l}+ \\
+\end{array}$ & & \\
\hline 20 & $78,1 \pm 0,5$ & $80,7 \pm 1,1$ & + & & \\
\hline 21 & & & & 85,8 & 89,4 \\
\hline
\end{tabular}

a) after mating at the moment of bloodmeal ;

$b$ ) after delayed mating of females, fed 110 days before.

Weights are expressed in \% of weight, at the moment of mating.

Student's t-test : $+=$ significant for $\mathrm{P}=0,95$

$-=$ non significant.

* value of t-test : $t=2,05$, which is significant for $\mathrm{P}=0,95$.

c) Effects on digestion : cytological analysis

Intracellular digestion is very active in mated females, since 4 or 5 days after bloodmeal. Later (about 2 weeks affter bloodmeal, midgut cells containing haemoglobin vacuoles are more numerous in virgin than in mated females (table II : 15-18 days, fig. 18, 19). They contain a well arranged rough endoplasmic reticulum (RER) with "whorl"'- like formations (fig. 20:R), whereas RER is formed by shorter, but numerous elements in the midgut cells of mated females ( $f i g$. 21). Undigested food ( $P$ in fig. 20) will hardly be found in the latter. Micropinocytotic activity is less important in midgut cells of mated than of virgin females, in which the midgut cells still absorb material from the lumen ( fig. 22).

\subsection{Effects of delayed mating on digestion in fasting ticks}

a) Gravimetric analysis

Delayed mating induces a significant weight loss in fasting females (table IVb). Normal eggs laid by females after delayed mating (table $V$ ) are less numerous than after mating synchronous with bloodmeal. After delayed mating, only $14 \%$ of the weight of tick (if $100 \%=$ at moment when the female starts laying eggs) are converted into eggs, as compared with $30 \%$ if, mating coincides with bloodmeal (table V). 
TABLE V - Parameters of egg-laying, both in natural case (normal oviposition following simultaneous bloodmeal and mating) and after delayed mating (occurring 110 days after bloodmeal).

\begin{tabular}{|c|c|c|}
\hline & $\begin{array}{c}\text { After mating } \\
\text { synchroneous with } \\
\text { bloodmeal }(\mathrm{n}=3)\end{array}$ & $\begin{array}{l}\text { After delayed } \\
\text { mating }(\mathrm{n}=3)\end{array}$ \\
\hline \multirow{5}{*}{$\begin{array}{l}\text { Number of eggs laid } \\
\text { Mean weight of a single egg (mg) } \\
\text { Weight of tick having laid eggs, } 25 \text { days } \\
\text { after mating ( } \% \text { of body weight at } \\
\text { moment of mating) } \\
\text { Total weight of eggs ( } \% \text { of body weight } \\
\text { of the tick starting to lay eggs) }\end{array}$} & 130 & 26 \\
\hline & 0,504 & 0,497 \\
\hline & & \\
\hline & 50,3 & 74,2 \\
\hline & 30,5 & 13,5 \\
\hline
\end{tabular}

\section{b) Histological analysis}

After delayed mating, histological evidence reveals an important triggering of digestive activity of midgut cells, linked with the mobilisation of food reserves stored in the midgut lumen (Aeschlimann and Grandjean, 1973a).

\subsection{Discussion}

\subsubsection{Effects of mating on nutrition}

Compared to ixodids, for which mating is an absolute necessity for completion of gorging (Aeschlimann and Grandjean, 1973a, including Ixodes ricimus, Graf, 1974), mating is not necessary for a normal nutrition in argasids.

\subsubsection{Effects of mating on digestion}

Our gravimetric results suggesting lower metabolic activity in virgin than in mated ticks agree with statements of Tatchell (1964) who found that haemoglobin concentration no longer diminishes after several days in unmated females, or with those of Galun and Warburg (1968) who could mimetic the slower protein digestion in virgin females by irradiating mated ones. Lowered digestive activity in virgin compared to mated females has also been reported from haematophagous insects (Edman, 1970, Pratt and Davey, 1972).

Our cytological results show that midgut cells of virgin females are able to store haemoglobin in phagosomes whithout actually digesting it immediately. Initiation of intracellular digestion by the fusion of primary lysosomes with such phagosomes could be delayed in the midgut of virgin ticks (Grandjean, in press). Protease level has been shown to remain constant over long periods in midguts of virgin females (Tatchell et al., 1972), which would agree with the hypothesis of a delayed intracellular digestion. Proteases would be synthetised, but not readily used up by the midgut cells.

In midgut cells of virgin females, the "whorl"-like arrangement of RER could suggest poor cellular activity of protein synthesis, as in midgut cells of fasting haema- 
tophagous insects (see Grandjean, in press). In relation to the slower digestion, nutrient reserves are stored in the midgut lumen of virgin females, even several months after bloodmeal (Aeschlimann and Grandjean, 1973a, Germond and Aeschlimann, 1977).

\subsubsection{Hypothetical endocrine relay of the triggering effect of mating on digestion}

Digestive activity of midgut cells appears to be regulated differently in mated or virgin females. It seems thus to be influenced by mating stimuli. Neurosecretory activity has been demonstrated to be linked to digestion (Gabbay and Warburg, 1976 : O. tholozani). Following delayed mating, neurosecretory cells become activated (Eisen et al., 1973 : Argas persicus). An endocrinally mediated, triggering action of mating on digestion is not to be excluded. In autogenic argasids, which lay eggs without previous bloodmeal as adults (Feldman-Muhsam, 1973, Aeschlimann and Grandjean, 1973b), digestion could be activated in a similar way to that observed after experimental delayed mating.

\section{REFERENCES}

Aeschlimann A., Grandjean O. : Influence of natural and "artificial" mating on feeding, digestion, vitellogenesis and egg laying in ticks (Ixodoidea). Folia parasilogia (Praha), r973a, $20,67-74$.

Aeschlimann A., Grandjean O. : Observations on fecundity in Ornithodorus moubata Murray (Ixodoidea : Argasidae). Relationships between mating and oviposition. Acarologia, 1973b, Is, 206-217.

Акоу S., Samish M., Galun R. : Protease activity in Female Ornithodorus tholozani Ticks. Acta trop., $1976,33,37-52$.

Balashov Y. S. : The structure of digestive organs and blood digestion in Argasidae (in russian). Parasitol. Sbornik, 1961, 20, 185-225.

Balashov Y. S. : Bloodsuching Ticks (Ixodoidea), Vectors of Diseases of Man and Animals. Misc. Pub. Ent. Soc. Amer., 1972, 8, 161-376.

Balashov Y. S., RAIKhel A. S. : Ultrafine structure of the midgut epithelium in nymphs of the tick Hyalomma asiaticum (Acarina, Ixodidae) (in russian). Parasitologia (Leningrad), 1976, IO, $201-209$.

Belozerov V. N., Tymopheev V. A. : An electron-microscope investigation of the midgut epithelium of adult female of Dermacentor marginatus Sulz. Proceedings 3 rd International Congress of Acarology, Prague, 1971, 707-715.

Boyde A., WOOD C. : Preparation of animal tissues for surface-scanning electron microscopy. J. Microscopy, 1969, $90,221-249$.

BurcK H. C. : Histologische Technik. Leitfaden für die Herstellung mikroskopischer Präparate in Unterricht und Praxis. Georg Thieme Verlag, Stuttgart, 1969, 183 p.

DIEHL P. A. : Zur Oogenese bei Ornithodorus moubata. Murray (Ixodoidea : Argasidae) unter besonderer Berücksichtigung der Vitellogenese. Acta Trop., I970, 27, 30I-355.

Ducommun J., Thesis in preparation, Institut de Zoologie, Neuchatel.

EDman J. D. : Rate of digestion of vertebrate blood in Aedes aegypti (L.). Effects of age, mating and parity. Am. J. Trop. Med. Hyg., 1970, I9, I03I-1033.

EISEN Y., WARBURG M. R., GALUN R. : Neurosecretory activity as related to feeding and oogenesis in the fowl-tick Argas persicus (Oken). Gen. Comp. Endocrinol., 1973, 21, 331-340.

Feldman-Muhsam B. : Autogeny in soft ticks of the genus Ornithodoros (Acari: Argasidae). J. Parasitol., 1973, $59,536-539$.

GABBAy S., WARBURG M. R. : Neurosecretory activity as related to feeding, mating and oogenesis in the female tick, Ornithodorus tholozani. J. Ins. Physiol., 1976, 22, 1291-1301.

Gabe M. : Techniques histologiques. Masson, Paris, 1968, I I 13 p.

GALUN R., WARBURG M. : Irradiation effects on respiration and blood digestion in the tick Ornithodoros tholozani, and their importance for the sterile-male technique. International Atomic Energy Agency, Vienna. "Isotopes and Radiation in Entomology", I968, p. 249-258.

Geigy R., Herbig A. : Erreger und Ueberträger tropischer Krankheiten. Acta Trop. Suppl. 6, I955, $\mathrm{I}-472$. 
Germond J. E., Aeschlimann A. : Influence of Copulation on Vitellogenesis and Egg-Laying in Ornithodorus moubata Murray (Ixodoidea : Argasidae). In : Adiyodi, K. G. and R. G. (eds). Advances in Invertebrate Reproduction Vol. I. (ISIR). Peralam-Kenoth, Karivellur, Kerala, India, $1977,308-318$.

Graf J. F. : Ecologie et éthologie d'Ixodes ricinus L. en Suisse (Ixodoidea ; Ixodidae). Troisième note : Copulation, nutrition et ponte. Acarologia, 1974, I6, 636-642.

Grandjean O. : Blood Digestion in Ornithodorus moubata Murray sensu stricto Walton (Ixodoidea, Argasidae) Females : I. Biochemical Changes in the Midgut Lumen and Ultrastructure of the Midgut Cell, Related to Intracellular Digestion. Acarologia (in press).

Grandjean O., Aeschlmann A. : Contribution to the Study of Digestion in Ticks : Histology and Fine Structure of the Midgut Epithelium of Ornithodorus moubata, Murray (Ixodoidea, Argasidae). Acta Trop., 1973, 30, 193-212.

Guirgis S. S. : The Subgenus Persicargas (Ixodoidea, Argasidae, Argas) I3. Histological Studies on $A$. (P.) arboreus Kaiser Hoogstraal and Kohls. J. Med. Ent., I971, 8, 648-667.

HajJar N. P. : Biochemical and Physiological Studies of Certain Ticks (Ixodoidea). Selection of Physiological States for Biochemical Analyses of Fluids. J. Med. Ent., I97 I, 8, 643-647.

Hecker H., Freyvogel T. A., Briegel H., Steiger R. : Ultrastructural Differentiation of the Midgut Epithelium in Female Aedes aegypti (L.) (Insecta : Diptera) Imagines. Acta Trop., I971a, 28, 80-104.

Hecker H., Freyvogel T. A., Briegel H., Steiger R. : The Ultrastructure of Midgut Epithelium in Aedes aegypti (L.). (Insecta, Diptera) Males. Acta Trop., I97 Ib, 28, 275-290.

Khalil G. M. : Biochemical and physiological studies of certain ticks (Ixodoidea). Incorporation of tritiated tyrosine in the digestive system of nymphal Argas (Persicargas) arboreus (Argasidae). Ann. Ent. Soc. Am., I971, 64, II 49-I I54.

Pearse A. G. E. : Histochemistry, Theoretical and Applied. Churchill, (Livingstone) ; Edinburgh and London, 3rd ed. : Vol I + II, I972, I5I 8 p.

Pratt G. E., DAvey K. G. : The corpus allatum and oogenesis in Rhodnius prolixus (Stäl). III. The effects of mating. J. Exp. Biol., 1972, s6, 223-237.

Tatchell R. J. : Digestion in the tick Argas persicus Oken. Parasitology, 1964, 54, 423-440. 